\title{
Analisis Kelayakan Finansial Usahatani Jeruk Siam (Citrus nobilis Lour.) Pada Usaha Yakin Maju Desa Pulau Jambu Kecamatan Kuok Kabupaten Kampar
}

\author{
Financial Feasibility Analysis of Siamese Orange (Citrus nobilis Lour.) \\ Farming at Usaha Yakin Maju in Pulau Jambu Village Kuok District Kampar Regency

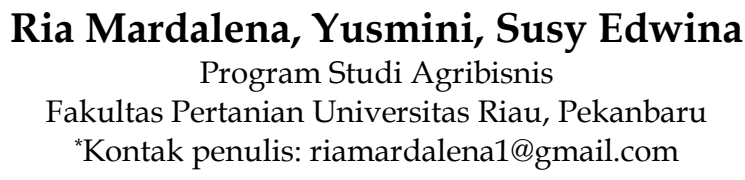

\begin{abstract}
This study aims to analyze the financial feasibility and sensitivity to price changes of the input and output of siamese orange Usaha Yakin Maju farming in Pulau Jambu Village Kuok District Kampar Regency. Usaha Yakin Maju is one of the farms that has been cultivating siamese orange since 2009 until now. This research uses the case study method. Reaserch data consist of primary data and secondary data. Data analysis was perfomed using four investment criteria, namely Net Present Value (NPV), Net Benefit Cost Ratio (Net B/C), Internal Rate of Return (IRR) and Payback Period (PP). The results showed that business activities carried out by Usaha Yakin Maju were financially feasible, indicated by a positive business NPV value of Rp.8.185.854.454,-, the Net B/C value is greater than one, which is 6,29, the IRR value is greater than the Social Opportunity Cost of Capital (SOCC) is 43,73\%, and the Paybak Period value is smaller than the age of the business, which is 4 years 9 months. The results of the sensitivity analysis to the increase in pesticide prices by 10\%, a decrease in prices of Siamese oranges by $20 \%$, and a decrease in the number of Siamese citrus production by $20 \%$ will reduce NPV, IRR, Net B/C, and PP but remain at the same level acceptable, indicate that this business is still financially feasible.
\end{abstract}

Keywords: siamese orange; farming; financial feasibility.

\begin{abstract}
Abstrak
Penelitian ini bertujuan untuk menganalisis kelayakan finansial dan sensitivitas terhadap perubahan harga input dan output usahatani jeruk siam pada Usaha Yakin Maju di Desa Pulau Jambu Kecamatan Kuok Kabupaten Kampar. Usaha Yakin Maju merupakan salah satu usahatani yang membudidaykan jeruk siam sejak 2009 hingga sampai saat ini. Penelitan ini menggunakan metode studi kasus. Data penelitian terdiri dari data primer dan data sekunder. Analisis data dilakukan dengan menggunakan empat kriteria investasi, yaitu Net Present Value (NPV), Net Benefit Cost Ratio (Net B /C), Internal Rate of Return (IRR), dan Payback Period (PP). Hasil penelitian menunjukkan bahwa kegiatan bisnis yang dilakukan Usaha Yakin Maju layak secara finansial, ditunjukkan oleh nilai NPV usaha yang positif sebesar Rp.8.185.854.454,-, Net B/C lebih besar dari satu yaitu 6,29, nilai IRR lebih besar dari Social Opportunity Cost of Capital (SOCC) sebesar 43,73\%, dan nilai PP lebih kecil dari umur usaha yaitu 4 tahun 9 bulan. Hasil analisis sensitivitas terhadap kenaikan harga pestisida sebesar $10 \%$, penurunan harga jeruk siam sebesar $20 \%$, dan penurunan jumlah produksi jeruk siam sebesar $20 \%$ akan menurunkan NPV, IRR, Net B/C, dan PP tetapi tetap pada tingkat yang dapat diterima, menunjukkan bahwa usaha ini masih layak secara finansial.
\end{abstract}

Kata kunci: jeruk siam; usahatani; kelayakan finansial. 


\section{Pendahuluan}

Sektor pertanian mempunyai peranan penting dalam perekonomian nasional, hal ini terlihat dari banyaknya jumlah penduduk Indonesia yang hidup dan bekerja di sektor tersebut. Sektor pertanian secara luas mencakup pertanian, perkebunan, perikanan, peternakan, dan kehutanan. Salah satu komoditi perkebunan hortikultura yang banyak diusahakan oleh petani di Indonesia adalah komoditi jeruk (Isaskar et al., 2011).

Tanaman jeruk merupakan tanaman yang sudah tidak asing lagi bagi masyarakat Riau, hal ini dikarenakan dahulu tanaman jeruk banyak diusahakan oleh petani-petani yang ada di Riau. Namun pada tahun 1980-an, eksistensi produksi yang dihasilkan tanaman jeruk di Kabupaten Kampar tidak dapat dipertahankan karena serangan penyakit CVPD (Citrus Vein Phloem Degeneration) yang merusak perkebunan jeruk secara besar-besaran (Saputra, 2012).

Salah satu potensi pertanian di Kabupaten Kampar yang berperan penting dalam perekonomian masyarakat daerah ini yaitu usahatani jeruk. Kabupaten Kampar memberikan kontribusi produksi jeruk yang cukup besar terhadap Provinsi Riau, total produksi jeruk pada tahun 2019 di kabupaten ini mencapai 105.677 ton. Produksi jeruk di Kabupaten Kampar mencapai 26,2\% dari total produksi di Provinsi Riau yakni sebesar 403.984 ton, sedangkan kabupaten penghasil jeruk terbesar adalah Kabupaten Rokan Hulu dengan produksi jeruk mencapai 60,7\% dari total produksi jeruk di Provinsi Riau (Provinsi Riau dalam Angka, 2020).

Kecamatan Kuok merupakan salah satu kecamatan produktif penghasil jeruk di Kabupaten Kampar. Total produksi jeruk ditahun 2018 di kecamatan ini mencapai 2.800 ton, jumlah ini meningkat $47 \%$ dari tahun 2017 dengan total produksi sebesar 1.480 ton (BPS Kecamatan Kuok, 2019). Salah satu desa penghasil jeruk siam di kecamatan ini adalah Desa Pulau Jambu. Mayoritas profesi penduduk Desa Pulau Jambu adalah petani, dan dengan berbagai usaha dibidang pertanian maupun non pertanian. Salah satu usahatani yang membudidayakan jeruk siam yakni Usaha Yakin Maju yang menjadi objek pada penelitian ini.

Tanaman jeruk merupakan tanaman buah-buahan tahunan dan membutuhkan investasi yang cukup besar, sehingga untuk pengembangan usahatani jeruk siam perlu dilakukan perhitungan aspek finansial. Perhitungan ini dapat dilihat dari biaya-biaya yang digunakan selama operasional usaha, serta pendapatan usaha yang diperoleh. Sejak awal berdiri, usaha yang dijalankan Usaha Yakin Maju belum pernah di evaluasi secara finansial. Analisis finansial sangat perlu dilakukan untuk melihat apakah usaha ini layak atau tidak dijalankan di masa mendatang dan seberapa besar kesiapan usaha ini dalam menghadapi kemungkinan risiko-risiko yang dapat terjadi, seperti kenaikan harga input, penurunan harga output, serta perubahan jumlah produksi. Berdasarkan uraian diatas, maka tujuan dari penelitian ini adalah menganalisis tingkat kelayakan finansial usahatani jeruk siam yang dijalankan Usaha Yakin Maju.

\section{Metode Penelitian}

Penelitian dilakukan pada Usaha Yakin Maju, alasan pemilihan lokasi ini berdasarkan pertimbangan bahwa usaha ini berkembang cukup baik sejak tahun 2009, Usaha Yakin Maju merupakan usahatani jeruk siam terluas di Desa Pulau Jambu dan belum pernah melakukan analisis kelayakan finansial terhadap usaha yang dijalankan. 
Penelitian ini menggunakan metode studi kasus, karena ruang lingkup penelitian ini adalah satu usaha budidaya dan memiliki objek penelitian secara khusus. Data yang digunakan adalah data primer dan data sekunder. Data primer diperoleh melalui wawancara langsung dengan pemilik Usaha Yakin Maju. Data sekunder diperoleh dari instansi terkait, yaitu buku atau dokumen dari instansi terkait seperti Kantor Desa Pulau Jambu, Badan Pusat Statistik, Dinas Pertanian Tanaman Pangan dan Hortikultura Kabupaten Kampar, penelitian terdahulu, perpustakaan dan beberapa literatur lain yang mendukung, serta lembaga-lembaga penunjang terkait.

Data primer terdiri dari data identitas responden, gambaran umum Usaha Yakin Maju, biaya-biaya yang dikeluarkan seperti biaya investasi dan biaya opernasional, jumlah penggunaan input selama umur produktif, jumlah produksi, serta harga input dan output yang berlaku. Biaya investasi adalah biaya yang dikeluarkan sebagai komitmen yang dilakukan pada saat ini, dengan tujuan memperoleh sejumlah keuntungan di masa yang akan datang (Suliyanto, 2010). Biaya operasional merupakan biaya yang rutin dikeluarkan setiap dilakukan usaha produksi dimana besar biaya tergantung pada jumlah produk yang ingin diproduksi (Rista, 2018). Data produksi diperoleh dari rata-rata produksi 5 tahun terakhir. Data harga yang dipakai adalah harga yang berlaku di daerah penelitian untuk selanjutnya harga diproyeksi menggunakan trend linier, non linear, dan analisis inflasi.

\section{Analisis data}

Penelitian ini menggunakan analisis kelayakan finansial dengan pendekatan analisis kriteria investasi : Net Present Value (NPV), Net Benefit Cost Ratio (Net B/C), Internal Rate of Return (IRR), dan Payback Period (PP).

\section{Net present value}

Net present value adalah kriteria investasi yang banyak digunakan untuk mengukur suatu usaha layak atau tidak. Net present value merupakan net benefit yang telah di-discount kan menggunakan Social Opportunity Cost of Capital (SOCC) sebagai discount factor (Ibrahim, 2009). Rumus Net Present Value adalah sebagai berikut:

$$
\mathrm{NPV}=\sum_{t=0}^{n}(B t-C t) /(1+i)^{t}
$$

\section{Keterangan :}

$\mathrm{Bt}=$ Benefit dalam usaha pada tahun ke-t (Rp/tahun)

$\mathrm{Ct} \quad$ = Biaya total yang dikeluarkan pada tahun ke-t $(\mathrm{Rp} / \mathrm{tahun})$

$\mathrm{n} \quad=$ Umur ekonomis usaha (tahun)

$\mathrm{i} \quad=$ Compound rate atau tingkat suku bunga $(\%)$

$\mathrm{t} \quad=$ Tahun $(0,1,2,3, \ldots)$

\section{Net benefit cost ratio $(\mathrm{Net} \mathrm{B} / \mathrm{C})$}

Net benefit cost ratio (Net B/C) merupakan perbandingan antara present value total benefit selama umur proyek dengan present value total cost selama umur proyek. Rumus untuk mencari net benefit cost ratio dirumuskan sebagai berikut (Imansari, 2016) :

$$
\text { Net B } / C=\frac{\sum_{t=0}^{\mathrm{n}} \mathrm{Bt}-\mathrm{Ct}(+)}{\sum_{\mathrm{t}=0}^{\mathrm{n}} \mathrm{Bt}-\mathrm{Ct}(-)}
$$




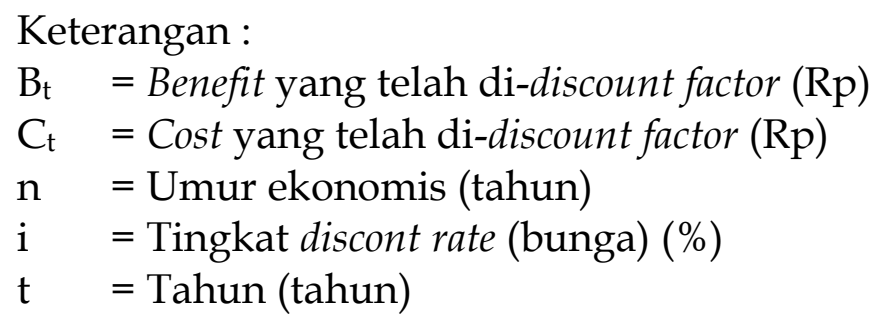

\section{Internal rate of return (IRR)}

Internal Rate of Return (IRR) adalah tingkat penghasilan investasi di proyek bersangkutan selama umur proyek dengan asumsi setiap manfaat yang masuk dapat diinvestasikan pada tingkat bunga yang sama. Nilai IRR tersebut juga merupakan discount rate yang membuat nilai $\mathrm{NPV}=0$. Rumus untuk mencari IRR dapat dirumuskan sebagai berikut (Pasaribu, 2012) :

$$
\mathrm{IRR}=\mathrm{i} 1+\frac{\mathrm{NPV}}{(\mathrm{NPV} 1-\mathrm{NPV} 2)} \mathrm{x}(\mathrm{i} 1-\mathrm{i} 2)
$$

Keterangan :

$\mathrm{i}_{2} \quad=$ tingkat discount rate yang menghasilkan NPV 1

$\mathrm{i}_{1} \quad=$ tingkat discount rate yang menghasilkan $\mathrm{NPV}_{2}$

$\mathrm{NPV}_{1}=\mathrm{NPV}$ yang nilai positif

$\mathrm{NPV}_{2}=\mathrm{NPV}$ yang nilai negatif

\section{Payback period (PP)}

Menurut Kasmir dan Jakfar (2012), metode payback period merupakan teknik penilaian terhadap jangka waktu (periode) pengembalian investasi suatu proyek atau usaha. Analisis payback period dihitung dengan cara menghitung waktu yang diperlukan pada saat total arus kas masuk sama dengan total arus kas keluar. Rumus untuk menghitung payback period (PP) adalah sebagai berikut (Umar, 2009) :

$$
\text { Payback period }(\mathrm{PP})=\mathrm{n}+(\mathrm{a}-\mathrm{b})(\mathrm{c}-\mathrm{b}) \times 1 \text { tahun }
$$

\section{Keterangan :}

$\mathrm{n}=$ Tahun terakhir di mana jumlah arus kas masih belum bisa menutup investasi mula-mula

a = Jumlah investasi mula-mula

$\mathrm{b}=$ Jumlah kumulatif arus kas pada tahun ke-n

c = Jumlah kumulatif arus kas pada tahun ke- $n+1$

Perhitungan analisis kriteria investasi membutuhkan beberapa pengolahan awal untuk mendapatkan proyeksi harga dan tingkat produksi dimasa yang akan datang. Proyeksi harga pada penelitian ini menggunakan analisis trend dan tingkat inflasi. Analisis trend digunakan pada data harga yang tersedia data historisnya kemudian dibandingkan dengan proyeksi tingkat inflasi untuk memperoleh proyeksi yang tepat, sedangkan analisis tingkat inflasi digunakan pada data yang tidak tersedia data historisnya. 


\section{Analisis trend}

Trend adalah salah satu peralatan statistik yang dapat digunakan untuk memperkirakan keadaan dimasa yang akan datang berdasarkan pada data masa lalu. Bentuk trend terdiri dari trend linier dan non linier (Pasaribu, 2012). Penelitian ini menggunakan analisis trend secara non linear dengan model trend kuadratik. Menurut Yohny (2013), cara penentuan trend kuadratik tidak banyak berbeda dari cara penentuan trend linear. Trend non linear adalah ukuran kecenderungan yang mempunyai model dengan persamaan pangkat dua, pangkat tiga, dan seterusnya. Kelebihan dari metode ini adalah sangat baik untuk data jangka panjang dan hasil ramalan mendekati nilai aktual. Alasan pemilihan metode ini karena selisih antara nilai data yang diproyeksikan dan data riil tidak berbeda jauh. Analisis trend digunakan untuk peramalan pertumbuhan dimasa mendatang untuk harga pestisida.

\section{Tingkat inflasi}

Inflasi adalah suatu proses meningkatnya harga-harga secara umum dan terusmenerus (kontinu), berkaitan dengan mekanisme pasar yang dapat disebabkan oleh faktor - faktor tertentu (Muchtar et al., 2016). Analisis tingkat inflasi digunakan untuk proyeksi biaya dimasa yang akan datang, pada beberapa koefisien teknis lainnya yaitu perhitungan biaya reinvestasi peralatan, biaya operasional, dan proyeksi harga output dengan menggunakan rata-rata tingkat inflasi Bank Indonesia periode tahun 2011-2020 yaitu $4,50 \%$.

\section{Analisis sensitivitas}

Analisis sensitivitas dilakukan untuk mengetahui akibat dari perubahan kinerja sistem produksi dalam menghasilkan keuntungan, dengan melakukan analisis sensitivitas maka akibat yang mungkin terjadi dari perubahan-perubahan tersebut dapat diketahui dan diantisifikasi sebelumnya (Departemen Agribisnis IPB,2015). Analisis sensitivitas dilakukan ketika hasil analisis kriteria investasi menyimpulkan bahwa usaha layak untuk dijalankan. Analisis sensitivitas pada penelitian ini dilakukan pada kondisi bila terjadi perubahan harga produksi (input), penurunan harga jual (output), dan penurunan hasil produksi, dimana persentase perubahan berdasarkan kondisi selama ini di Usaha Yakin Maju.

\section{Hasil dan Pembahasan}

\section{Profil usaha}

Usaha Yakin Maju merupakan salah satu produsen jeruk siam di Desa Pulau Jambu Kecamatan Kuok, dengan luas lahan 7,5 hektar yang dikelola oleh Bapak Riko selaku pemilik usaha. Usaha ini yang sudah berjalan sejak tahun 2009 sampai sekarang, artinya usaha ini memiliki perkembangan yang baik. Usahatani ini merupakan usaha jeruk siam terluas yang berada di Desa Pulau Jambu. Usaha Yakin Maju dibuka diatas lahan kosong seluas 7,5 hektar, dimana proses pembukaan lahan dilakukan sekaligus pada tahun pertama. Usaha Yakin Maju menanam bibit jeruk jenis Siam Banjar yang dibeli dari pembibitan Desa Pulau Jambu sebanyak 3000 bibit yang sudah berumur 6 bulan, dimana setiap hektar ditanam 400 bibit jeruk sekaligus pada tahun pertama dengan pola tanam monokultur dan jarak tanam $5 \mathrm{~m} \times 5 \mathrm{~m}$. Usaha Yakin Maju dalam berusaha tani rutin melakukan pemeliharaan tanaman dengan harapan agar produksi 
yang dihasilkan lebih optimal. Pemeliharaan yang dilakukan usaha ini meliputi penyiangan, penggemburan, pemangkasan, pemupukan dan penyemprotan.

Tanaman jeruk siam belum bisa menghasilkan buah sampai tanaman berumur 3 tahun setelah tanam, setelah tahun ke-3 petani dapat menerima hasil. Tanaman jeruk siam dapat berproduksi selama kurang lebih 15 tahun. Tanaman jeruk rata-rata berbunga sepanjang tahun dikarenakan bunga jeruk tidak mengenal musim, maka buah jeruk tersedia setiap saat. Begitupula pada Usaha Yakin Maju, setiap minggu usaha ini mampu menyediakan permintaan buah jeruk sesuai dengan permintaan pasar baik pedagang pengumpul maupun konsumen langsung, berkisar 1-6 ton jeruk siam. Panen raya pada usaha ini terjadi dua kali setahun yaitu pada bulan April dan Agustus dengan masa panen berlangsung 1 bulan.

\section{Asumsi-asumsi}

Analisis finansial usahatani jeruk siam pada Usaha Yakin Maju mempertimbangkan berbagai asumsi yang berhubungan dengan pembudidayaan jeruk siam. Asumsi-asumsi yang digunakan dalam analisis ini adalah sebagai berikut:

1. Umur usaha adalah 15 tahun, didasarkan oleh umur produktif jeruk.

2. Investasi awal pada tahun 2020

3. Tingkat suku bunga yang digunakan adalah tingkat suku bunga bank umum yang berlaku di masyarakat yaitu 9,55\% per tahun. Tingkat bunga ini dipilih karena mengikuti Bank Umum di Kecamatan Kuok Kabupaten Kampar.

4. Inflasi yang digunakan yaitu 4,50\% merupakan rata-rata inflasi Bank Indonesia periode tahun 2011-2020.

5. Biaya investasi untuk tahun 0 sampai tahun ke 3 data diperoleh dari petani informan, dengan harga yang berlaku di tahun 2020.

6. Harga jual jeruk siam menggunakan harga rata-rata jeruk siam pada tahun 2020 yakni Rp.9.667/kg didapat dari rata-rata jumlah harga jeruk siam dua bulan panen raya $\mathrm{Rp} .8 .000 / \mathrm{kg}$ dan sepuluh bulan harga normal Rp.10.000/kg yang dijual dalam sistem borongan (tanpa grading).

7. Data produksi jeruk siam dilihat berupa data penelitian Rista pada tahun 2018 di Nagari Koto Tinggi, menjelaskan bahwa produksi jeruk siam pada umur tanam tahun ke-3 sebanyak 1,9 ton/ha sedangkan produksi jeruk siam umur tanam tahun ke-15 yaitu sebanyak 16,8 ton/ha. Berdasarkan data produksi Nagari Koto Tinggi dan hasil pengamatan di lapangan terhadap produksi jeruk siam yang dihasilkan Usaha Yakin Maju, rata-rata jumlah selisih atau persentase perbedaan produksi sebesar 17\% atau 7,04 ton/ha/tahun, dengan perbedaan selisih tersebut maka produksi Usaha Yakin Maju dapat diproyeksi untuk umur tanam tahun sebelumnya dengan asumsi bahwa produksi Nagari Koto Tinggi dan produksi jeruk siam Usaha Yakin Maju memiliki trend yang sama. Data produksi jeruk siam yang didapat berumur tanam 7-11 tahun diperoleh dari Usaha Yakin Maju dan produksi untuk umur tanam tahun sebelumnya diasumsikan memiliki trend yang sama dengan data produksi Nagari Koto Tinggi.

8. Upah tenaga kerja ditetapkan berdasarkan upah yang berlaku di lokasi penelitian.

9. Upah penjaga kebun ditentukan Usaha Yakin Maju sebesar Rp.1.500.000 setiap bulan.

10. Proyeksi data harga menggunakan dua pendekatan yaitu pendekatan peramalan dengan analisis trend dan pendekatan tingkat inflasi. Perhitungan trend digunakan 
untuk meramal data yang tersedia data historisnya, sedangkan perhitungan dengan tingkat inflasi dipakai untuk data-data yang tidak tersedia data historisnya.

11. Trend non linear digunakan untuk proyeksi harga pestisida.

12. Tingkat inflasi digunakan untuk proyeksi harga jual jeruk siam, harga pupuk, harga peralatan, dan pendukung lain.

\section{Penerimaan}

Nilai NPV, Net B/C, IRR, dan PP dipengaruhi oleh nilai penerimaan dan biaya. Penerimaan merupakan hasil dari penjualan produk yang didapat dari perkalian harga jual dengan jumlah produksi. Hasil produksi Usaha Yakin Maju berupa buah jeruk siam segar. Usahatani jeruk siam mulai berproduksi pada umur tanaman ketiga, sehingga petani mulai mendapatkan penerimaan pada tahun ketiga.

Tabel 1

Benefit Usahatani Jeruk Siam Periode 2020-2035 di Usaha Yakin Maju

\begin{tabular}{rrrrr}
\hline & \multicolumn{1}{c}{ Tahun } & $\begin{array}{c}\text { Produksi } \\
(\mathbf{k g} / \mathbf{t h n})\end{array}$ & Harga $\mathbf{( R \mathbf { p } / \mathbf { k g } )}$ & Benefit (Rp/tahun) \\
\hline 0 & 2020 & - & 9.667 & - \\
1 & 2021 & - & 10.102 & - \\
2 & 2022 & - & 10.556 & - \\
3 & 2023 & 11.520 & 11.031 & 122.844 .251 \\
4 & 2024 & 161.280 & 11.528 & 1.797 .211 .392 \\
5 & 2025 & 201.600 & 12.046 & 2.347 .607 .381 \\
6 & 2026 & 201.600 & 12.589 & 2.453 .249 .714 \\
7 & 2027 & 230.400 & 13.155 & 2.929 .881 .087 \\
8 & 2028 & 240.000 & 13.747 & 3.189 .297 .641 \\
9 & 2029 & 240.000 & 14.366 & 3.332 .816 .035 \\
10 & 2030 & 249.600 & 15.012 & 3.622 .104 .467 \\
11 & 2031 & 288.000 & 15.688 & 4.367 .422 .117 \\
12 & 2032 & 259.200 & 16.394 & 4.107 .560 .501 \\
13 & 2033 & 172.800 & 17.131 & 2.861 .600 .482 \\
14 & 2034 & 115.200 & 17.902 & 1.993 .581 .669 \\
15 & 2035 & 100.800 & 18.708 & 1.822 .881 .239 \\
\hline \multicolumn{5}{r}{} \\
\hline
\end{tabular}

Tabel 1 menunjukkan jumlah produksi sesuai dengan umur tahun tanaman jeruk siam. Jumlah produksi jeruk siam tersebut diasumsikan sama atau tidak terjadi perubahan kenaikan atau penurunan produksi apabila terjadi panen raya, namun untuk harga jeruk siam dilakukan perhitungan harga normal dengan harga fluktuasi ketika terjadi panen raya di Bulan April dan Bulan Agustus sehingga diperoleh sepuluh bulan menggunakan harga normal dan dua bulan menggunakan harga normal dikurangi dengan 20 persen harga panen raya. Benefit tertinggi yang diperoleh petani jeruk siam Usaha Yakin Maju pada saat umur tanaman mencapai tahun ke-11 dimana jumlah benefit sebesar Rp.4.367.422.117 atau Rp.582.322.949 per hektar, dengan jumlah produksi jeruk siam sebanyak $288.000 \mathrm{~kg}$ dan harga Rp.15.688. Total benefit yang diperoleh petani dari hasil penjualan jeruk siam selama umur usaha adalah sebesar Rp.34.948.057.975. 


\section{Biaya usahatani jeruk siam}

Biaya usahatani merupakan seluruh pengeluaran yang dikeluarkan petani pada saat melaksanakan usahatani. Komponen biaya ini terdiri dari biaya investasi dan biaya operasional. Biaya investasi merupakan biaya-biaya yang dikeluarkan oleh petani jeruk siam sebelum tanaman menghasilkan, yaitu pada saat awal mulai usaha hingga tanaman berproduksi (0-2 tahun). Biaya-biaya yang tergolong dalam biaya investasi terdiri dari biaya pembukaan lahan, pembangunan pondok, pembelian pupuk dasar, pembelian bibit, dan pembelian sarana pendukung seperti peralatan. Total biaya investasi yang dikeluarkan oleh Usaha Yakin Maju adalah sebesar Rp 1.360.490.198.

Tabel 2

Total Biaya Investasi Usahatani Jeruk Siam Belum Menghasilkan Pada Usaha Yakin Maju Tahun 2020-2022

\begin{tabular}{|c|c|c|c|}
\hline No & Rincian & Biaya & Persentase \\
\hline \multirow[t]{11}{*}{1} & Tahun Tanam 0 & & \\
\hline & a. Biaya lahan & 660.000 .000 & $48,51 \%$ \\
\hline & b. Pembangunan pondok & 28.500 .000 & $2,09 \%$ \\
\hline & c. Biaya pembelian peralatan & 24.415 .000 & $1,79 \%$ \\
\hline & d. Pembelian bibit dan penanaman & 45.000 .000 & $3,31 \%$ \\
\hline & e. Pemupukan dasar & 64.500 .000 & $4,74 \%$ \\
\hline & f. Biaya TK penjaga kebun & 18.000 .000 & $1,32 \%$ \\
\hline & g. Biaya listrik & 4.800 .000 & $0,35 \%$ \\
\hline & h. Biaya BBM & 2.792 .250 & $0,21 \%$ \\
\hline & i. PBB lahan & 450.000 & $0,03 \%$ \\
\hline & Subtotal & 848.457 .250 & $62,36 \%$ \\
\hline \multirow[t]{10}{*}{2} & Tahun Tanam 1 & & \\
\hline & a. Biaya TK Pemeliharaan & 70.537 .500 & $5,18 \%$ \\
\hline & b. Biaya TK Penjaga Kebun & 18.810 .000 & $1,38 \%$ \\
\hline & c. Penambahan Peralatan & 11.129 .250 & $0,82 \%$ \\
\hline & d. Biaya Pupuk & 76.180 .500 & $5,60 \%$ \\
\hline & e. Biaya Pestisida & 48.302 .888 & $3,55 \%$ \\
\hline & f. Biaya Listrik & 5.016 .000 & $0,37 \%$ \\
\hline & g. Biaya BBM & 17.307.551 & $1,27 \%$ \\
\hline & h. PBB Lahan & 470.250 & $0,03 \%$ \\
\hline & Subtotal & 247.753 .940 & $18,21 \%$ \\
\hline \multirow[t]{10}{*}{3} & Tahun Tanam 2 & & \\
\hline & a. Biaya TK Pemeliharaan & 54.251 .802 & $3,99 \%$ \\
\hline & b. Biaya TK Penjaga Kebun & 19.656 .450 & $1,44 \%$ \\
\hline & c. Penambahan Peralatan & 191.104 & $0,01 \%$ \\
\hline & d. Biaya Pupuk & 79.608 .623 & $5,85 \%$ \\
\hline & e. Biaya Pestisida & 86.729 .394 & $6,37 \%$ \\
\hline & f. Biaya Listrik & 5.241 .720 & $0,39 \%$ \\
\hline & g. Biaya BBM & 18.086.391 & $1,33 \%$ \\
\hline & h. PBB lahan & 513.525 & $0,04 \%$ \\
\hline & Subtotal & 264.279.009 & $19,43 \%$ \\
\hline \multicolumn{2}{|c|}{ Total investasi tahun tanam $0-2$} & 1.360 .490 .198 & $100 \%$ \\
\hline
\end{tabular}


Biaya operasional merupakan biaya rutin dalam kegiatan operasional sehari-hari baik operasi produksi, penunjang sarana, maupun penunjang administratif lainnya yang bermanfaat kurang dari satu tahun. Tanaman jeruk siam dalam usaha selama 15 tahun rutin mengeluarkan biaya produksi yaitu biaya tenaga kerja pemeliharaan, biaya panen, biaya penjaga kebun, biaya bahan bakar minyak, biaya listrik, serta biaya pajak bumi dan bangunan. Biaya tenaga kerja pemeliharaan terdiri dari biaya penyiangan, penggemburan, pemangkasan, pemupukan dan penyemprotan. Total biaya operasional yang dikeluarkan oleh Usaha Yakin Maju selama menjalankan usaha sebesar Rp.13.209.609.661.

\section{Perhitungan kriteria investasi}

Berikut adalah hasil perhitungan kriteria investasi usahatani jeruk siam Usaha Yakin Maju di Desa Pulau Jambu Kecamatan Kuok Kabupaten Kampar.

Tabel 3

Nilai Kriteria Investasi Usaha Yakin Maju 2020-2035

\begin{tabular}{lr}
\hline Kriteria Investasi & Nilai \\
\hline NPV & 8.185 .854 .454 \\
Net B/C & 6,29 \\
IRR & $43,73 \%$ \\
PP & 4 tahun 9 bulan \\
Rata-rata NPV per tahun & 545.723 .630 \\
Rata-rata NPV per bulan & 45.474 .969 \\
\hline
\end{tabular}

Tabel 3 menunjukkan bahwa nilai NPV selama umur usaha sebesar Rp.8.185.854.454, artinya dengan tingkat suku bunga 9,55\% usaha tersebut akan memberikan keuntungan sebesar Rp.8.185.854.454 dengan rata-rata keuntungan per bulan Rp.45.474.969 atau sebesar Rp.6.063.596 per hektar menurut nilai waktu uang sekarang. Nilai Net B/C diatas satu yaitu 6,29, artinya setiap pengeluaran Rp.1 maka akan menghasilkan pendapatan sebesar Rp.6,29. Nilai IRR lebih besar dari Social Opportunity Cost of Capital (SOCC) yaitu 43,73\%, artinya pada saat tingkat suku bunga $43,73 \%$ nilai NPV yang dihasilkan sama dengan nol dan pada tingkat suku buga tersebut usahatani jeruk siam masih bisa melakukan pengembalian terhadap investasi yang dikeluarkan karena nilai IRR lebih besar dari SOCC yaitu 9,55. Nilai PP lebih kecil dari umur usaha yaitu 4 tahun 9 bulan, artinya dalam jangka waktu 4 tahun 9 bulan usaha ini mampu mengembalikan modal yang dikeluarkan. Semua hasil perhitungan memenuhi standar indikator kelayakan, nilai NPV positif atau besar daripada satu, nilai Net B/C besar atau sama dengan satu, nilai IRR lebih besar dari tingkat suku bunga yang berlaku (SOCC), dan nilai PP lebih kecil dari umur usaha, berdasarkan hal tersebut dapat disimpulkan bahwa usahatani jeruk Siam yang dijalankan oleh Usaha Yakin Maju layak secara finansial.

Hasil penelitian Rantau (2016), usaha perkebunan jeruk siam di Desa Sekaan Kecamatan Kintamani Kabupaten Bangli memiliki nilai NPV sebesar Rp.10.140.253.940, nilai IRR sebesar 25\%, nilai Net B/C sebesar 4,89, dan Payback Period selama 6,5 tahun atau lebih kecil dari umur proyek. Hasil penelitian Rista (2018), usahatani jeruk siam gunung omeh Kabupaten Lima Puluh Kota, memiliki nilai NPV positif sebesar Rp.1.296.505.841, nilai Net B/C lebih besar dari 1 yaitu 6,66, nilai IRR lebih besar dari 
Social Opportunity Cost of Capital (SOCC), dan payback period (PP) selama 4 tahun 8 bulan lebih kecil dari umur usaha yaitu 15 tahun.

\section{Analisis sensitivitas}

Analisis sensitivitas bertujuan untuk melihat dampak dari suatu keadaan yang berubah-ubah terhadap kondisi kelayakan suatu usaha, apabila terjadi perubahan pada variabel-variabel risiko yang dianggap penting, kemudian dinilai seberapa besar sensitivitas perubahan variabel-variabel tersebut berdampak pada hasil kelayakan pengembangan. Analisis sensitivitas untuk usahatani jeruk siam Usaha Yakin Maju dilakukan dengan melihat pengaruh perubahan tiga faktor terhadap nilai NPV, Net B/C, IRR, dan PP yang mungkin terjadi selama proses produksi. Tiga faktor yang dilihat yaitu: tingkat produksi, harga input dan harga output.

1. Analisis sensitivitas terhadap perubahan harga input

Harga input dalam analisis sensitifitas ini yang diubah yaitu harga pestisida, dikarenakan harga input tersebut sering mengalami perubahan harga pada setiap tahun. Kenaikan harga input tersebut mengakibatkan pendapatan petani jeruk siam Usaha Yakin Maju menurun. Kenaikan harga input tertinggi yang pernah terjadi pada Usaha Yakin Maju yaitu sebesar 10\%.

Tabel 4

Perubahan Nilai NPV, Net B/C, IRR, dan PP

Terhadap Kenaikan Harga Input 10\% Usahatani Jeruk Siam Periode 2020-2035

\begin{tabular}{lcrrr}
\hline Kriteria Investasi & NPV & Net B/C & \multicolumn{1}{l}{ IRR } & \multicolumn{1}{c}{ PP } \\
\hline Sensitivitas 10\%+ & 7.937 .863 .169 & 6,08 & $43,11 \%$ & 4 tahun 10 bulan \\
Analisis awal & 8.185 .854 .454 & 6,29 & $43,73 \%$ & 4 tahun 9 bulan \\
\hline
\end{tabular}

Hasil perhitungan analisis sensitivitas menunjukan bahwa dengan harga pestisida yang meningkat sebesar 10\%, maka usahatani jeruk siam Usaha Yakin Maju tetap layak untuk dijalankan secara teori, karena semua kriteria investasi masih memenuhi standar dimana nilai NPV masih bernilai positif, nilai Net B/C lebih besar dari satu, nilai IRR lebih besar dari SOCC yang ditentukan (9,55\%) dan PP lebih kecil dari umur usaha.

2. Analisis sensitivitas terhadap perubahan harga output

Harga output adalah harga yang ditentukan oleh petani atau pembeli terhadap suatu produk, oleh karena itu perubahan harga output perlu dilihat dalam analisis sensitivitas. Salah satu faktor yang mempengaruhi besar kecil penerimaan petani jeruk siam adalah penurunan harga output. Perubahan harga jeruk siam yang pernah terjadi pada Usaha Yakin Maju yaitu sebesar 20\%, besar perubahan tersebut berdasarkan penurunan harga jeruk siam di lokasi penelitian pada saat panen raya.

Tabel 5

Perubahan Nilai NPV, Net B/C, IRR, dan PP 
Terhadap Penurunan Harga Jeruk Siam 20\% Periode 2020-2035

\begin{tabular}{lcrrc}
\hline \multicolumn{1}{c}{ Kriteria Investasi } & NPV & Net B/C & \multicolumn{1}{l}{ IRR } & PP \\
\hline Sensitivitas 20\%- & 5.578 .092 .143 & 4,57 & $36,73 \%$ & 5 tahun 4 bulan \\
Analisis awal & 8.185 .854 .454 & 6,29 & $43,73 \%$ & 4 tahun 9 bulan \\
\hline
\end{tabular}

Hasil analisis sensitivitas terhadap penurunan harga jeruk siam $20 \%$ dengan jumlah produksi tetap dan biaya tetap, maka terjadi penurunan nilai NPV menjadi Rp.5.578.092.143 namun masih positif, nilai Net B/C yaitu 4,57, nilai IRR berada pada DF 36,73\%, dan nilai payback period selama 5 tahun 4 bulan. Hal ini menunjukkan dengan harga jeruk siam yang menurun sebesar 20\%, maka usahatani jeruk siam Usaha Yakin Maju tetap layak untuk dilanjutkan secara teori karena semua kriteria investasi masih memenuhi standar dimana NPV masih bernilai positif, nilai Net B/C lebih besar dari satu, nilai IRR lebih besar dari SOCC yang ditentukan $(9,55 \%)$, dan payback period lebih kecil dari umur usaha.

3. Analisis sensitivitas terhadap perubahan jumlah produksi

Perubahan variabel lain yang dilihat dalam analisis sensitivitas Usaha Yakin Maju adalah penurunan jumlah produksi jeruk siam. Penurunan jumlah produksi akan sangat berpengaruh terhadap benefit yang diterima. Penurunan jumlah produksi jeruk siam terbesar yang pernah terjadi pada Usaha Yakin Maju yaitu sebesar 20\%.

\section{Tabel 6}

Perubahan Nilai NPV, Net B/C, IRR, dan PP

Terhadap Penurunan Produksi Jeruk Siam 20\% Periode 2020-2035

\begin{tabular}{lcrrc}
\hline \multicolumn{1}{c}{ Kriteria Investasi } & NPV & Net B/C & \multicolumn{1}{l}{ IRR } & PP \\
\hline Sensitivitas 20\%- & 5.369 .471 .158 & 4,43 & $36,10 \%$ & 5 tahun 5 bulan \\
Analisis awal & 8.185 .854 .454 & 6,29 & $43,73 \%$ & 4 tahun 9 bulan \\
\hline
\end{tabular}

Hasil perhitungan analisis sensitivitas terhadap penurunan jumlah produksi jeruk siam sebesar $20 \%$ dengan harga produksi tetap, maka terjadi penurunan NPV menjadi Rp.5.369.471.158 namun masih positif, nilai Net B/C lebih besar dari satu yaitu 4,43, nilai IRR berada pada DF 36,10\%, dan nilai payback period selama 5 tahun 5 bulan. Hal ini menunjukkan dengan jumlah produksi yang menurun sebesar 20\%, maka usahatani jeruk siam Usaha Yakin Maju tetap layak untuk dilanjutkan secara teori karena semua kriteria investasi masih memenuhi standar dimana NPV masih bernilai positif, Net B/C lebih besar dari satu, nilai IRR lebih besar dari SOCC yang ditentukan (9,55\%), dan payback period kecil dari umur usaha.

\section{Kesimpulan}

Hasil penelitian ini menunjukkan bahwa usahatani jeruk siam Usaha Yakin Maju di Desa Pulau Jambu Kecamatan Kuok Kabupaten Kampar melalui analisis kelayakan finansial menunjukkan layak diusahakan karena mampu memperoleh tingkat pengembalian yang memenuhi standar kelayakan, dengan nilai NPV positif sebesar Rp.8.185.854.454 untuk umur ekonomis 15 tahun dan luas lahan 7,5 hektar. Nilai Net B/C yang didapat lebih besar dari 1 yaitu 6,29, nilai IRR 43,73\% lebih tinggi dari discount factor (DF) yang digunakan yaitu 9,55\%, dan nilai payback period yakni 4 tahun 9 bulan lebih kecil dari umur usaha. Hasil analisis sensitivitas terhadap 3 faktor yaitu 
peningkatan harga input jeruk siam sebesar $10 \%$, penurunan harga jeruk siam sebesar $20 \%$, dan penurunan jumlah produksi jeruk siam sebesar $20 \%$ akan menurunkan NPV, IRR, Net B/C, dan PP tetapi masih pada tingkat yang dapat di terima. Analisis sensitivitas terhadap penurunan produksi jeruk siam sebesar 36,10\% adalah batas maksimum penurunan produksi, apabila lewat dari 36,10\% maka usahatani jeruk siam Usaha Yakin Maju tidak layak dijalankan dan dikembangkan, karena nilai NPV negatif, Net B/C lebih kecil dari 1, dan IRR lebih kecil dari SOCC yang ditentukan yaitu 9,55\%.

\section{Daftar Pustaka}

Badan Pusat Statistik Kabupaten Kampar. (2019). Kecamatan Kuok dalam Angka 2020. Badan Pusat Statistik Kabupaten Kampar. Bangkinang Kota.

Badan Pusat Statistik Provinsi Riau. (2020). Provinsi Riau dalam Angka 2020. Badan Pusat Statistik Provinsi Riau. Kota Pekanbaru.

Departemen Agribisnis FEM-IPB. (2015). Analisis Sensitivitas - Studi Kelayakan Bisnis. Bandung.

Ibrahim, Y. (2009). Studi Kelayakan Bisnis. Edisi revisi. Rineka Cipta. Jakarta.

Imansari, D. (2016). Analisis Kelayakan Finansial Pengembangan Usahatani Pepaya California Di Kabupaten Lampung Selatan Provinsi Lampung. Skripsi (Tidak dipublikasikan). Universitas Lampung. Bandar Lampung.

Isaskar, R., S., dan N. Tanda. (2011). Efisiensi Pemasaran Jeruk Pamelo dalam Wilayah Magetan (Citrus grandis L. Osbek). Jurnal Habitat. 22(1): 61-70.

Kasmir, J. (2012). Studi Kelayakan Bisnis, Edisi Revisi. Kencana, Jakarta.

Muchtar. et al. (2016). Bank dan Lembaga Keuangan Lainnya. Kencana. Jakarta.

Pasaribu, A. M. (2012). Perencanaan \& Evaluasi Proyek Agribisnis. Lily Publisher. Yogyakarta.

Rantau, I. K. et al. (2016). Kelayakan finansial usaha perkebunan jeruk siam di Desa Sekaan Kecamatan Kintamani Selatan Kabupaten Bangli. E-Jurnal Agribisnis dan Agrowisata, 5(4).

Rista. (2018). Analisis Kelayakan Finansial Usahatani Jeruk Siam Gunung Omeh (Citrus nobilis Lour.) (Studi Kasus Nagari Koto Tinggi Kecamatan Gunung Omeh Kabupaten Lima Puluh Kota Provinsi Sumatera Barat)". Skripsi (Tidak dipublikasikan). Universitas Riau. Pekanbaru .

Saputra, S. et al. (2012). Pengendalian penyakit CVPD (Citrus Vein Phloem Degeneration). Balai Pengkajian Teknologi Pertanian Riau. Pekanbaru

Suliyanto. (2010). Studi Kelayakan Bisnis. Andi. Yogyakarta.

Yohny, Y. (2013). Metode Trend Non Linear Untuk Forecasting Jumlah Keberangkatan Tenaga Kerja Indonesia Di Kantor Imigrasi kelas II Kabupaten Nunukan. Jurnal Eksponensial. 4(1): 47-54 